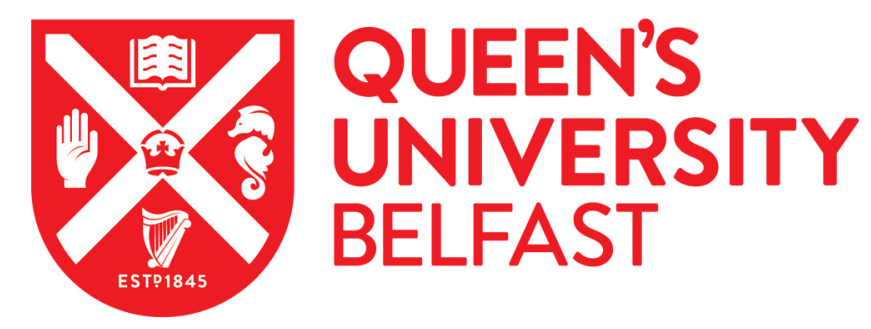

\title{
Devulgarizing Dickens: Andrew Lang, Homer and the Rise of Psycho- Folklore
}

Sumpter, C. (2020). Devulgarizing Dickens: Andrew Lang, Homer and the Rise of Psycho-Folklore. ELH, 87(3), 733. https://doi.org/10.1353/elh.2020.0026

\author{
Published in: \\ ELH
}

Document Version:

Peer reviewed version

Queen's University Belfast - Research Portal:

Link to publication record in Queen's University Belfast Research Portal

Publisher rights

Copyright 2019 Johns Hopkins University Press. This work is made available online in accordance with the publisher's policies. Please refer to any applicable terms of use of the publisher.

\section{General rights}

Copyright for the publications made accessible via the Queen's University Belfast Research Portal is retained by the author(s) and / or other copyright owners and it is a condition of accessing these publications that users recognise and abide by the legal requirements associated with these rights.

Take down policy

The Research Portal is Queen's institutional repository that provides access to Queen's research output. Every effort has been made to ensure that content in the Research Portal does not infringe any person's rights, or applicable UK laws. If you discover content in the Research Portal that you believe breaches copyright or violates any law, please contact openaccess@qub.ac.uk. 
Devulgarizing Dickens: Andrew Lang, Homer and the Rise of Psycho-Folklore

In 1895, Andrew Lang proclaimed himself the lone member of a new "sect", a "member with no 'society"': he was, he announced playfully, the only "psycho-folklorist". Lang's bold intellectual endeavor occurred at the intersection of psychology, which dealt "with the individual patient", and folklore, which examined "the symptoms as exhibited by the race." 1 In the critical essays for the thirty-four volumes of the Chapman and Hall Gadshill Dickens (1898-99), Lang showcased his skills as psycho-folklorist, championing a mythic Dickens whose fiction tapped into humans' earliest feelings and mental impulses. The neglected Gadshill volumes mark a fascinating moment in the convergence of anthropological, psychoanalytic and occult readings of Dickens. ${ }^{2}$ Lang would not for long remain in a club of one.

Psycho-folklore worked its magic on some notable turn-of-the-century Dickens critics, attracting both practitioners and opponents of decadent art. The Gadshill volumes reveal that psycho-folkloric interpretations of Dickens were flourishing nearly twenty years before Carl Jung coined the term collective unconscious, or argued for the significance of mythic archetypes as primitive survivals in the human mind. ${ }^{3}$ The Dickens of psycho-folklore - part Romantic genius, part "savage survival" - was shaped by the ethnocentrism of its late nineteenth-century moment, but it also raised questions that would remain active in twentiethcentury literary criticism. Did Dickens have the rare power to summon up the subconscious, and subject it to literary reflection? Or did he not reflect much at all: was he simply the unknowing psychological clay that awaited the expert interpretation of others?

The Dickens of psycho-folklore could never become a fully autonomous literary agent: he had to serve as both the individual patient of psychology, and the folk mind that embodied the symptoms of the race. This critical approach, which made history and authorial intention disappear, left its own historical legacy. At the beginning of the twentieth century, Arthur 
Machen claimed that the Pickwick Papers channeled the same impulses as Bacchanalian rites, while G. K. Chesterton announced that "Dickens did not strictly make a literature; he made a mythology." ${ }^{4}$ Here, I show that psycho-folklore, despite its claims for Dickens's timeless genius, truly meant looking backwards: imagining popular culture as the product of a primitive past.

Lang's construction of Dickens as a writer who was linked to racial and psychological prehistory raises obvious questions about attempts to reconcile literary value and commercial fiction at the end of the nineteenth century. The dismissal of Lang as an amateur by some contemporaries has received more attention than the respect that he was accorded as an anthropologist and translator of Homer. ${ }^{5}$ His expertise in those fields, I argue here, was central to Lang's rehabilitation of Dickens. For Lang was acutely aware that his intended audience included "ladies" who found "Dickens vulgar". 6

While Susan Bernstein and Elsie Michie have argued that the concept of vulgarity "was beginning to lose its bite" by the end of the nineteenth century, Dickens's critics remained highly sensitive to the damage this nebulous term continued to inflict on the author. ${ }^{7}$ George Gissing, in Dickens: A Critical Study (1898), sought to discriminate between vulgarity in terms of subject matter ("vulgar" was still deemed an appropriate descriptor for the class and manners of some of Dickens's characters) and vulgarity as a term that applied to Dickens's style. "Dealing for the most part with vulgarity, his first book is very free from vulgarisms", was Gissing's succinct conclusion. ${ }^{8}$ Chesterton, who claimed in 1911 that "all that Victorian universe" in which Dickens "seemed vulgar" was "breaking up like a cloudland", still felt the need to defend the grammatical "vulgarism" in the title of Our Mutual Friend; he would go on to use the terms "vulgar" or "vulgarity" more than twenty times. ${ }^{9}$ The Dickens of psychofolklore - supposedly appealing to the same part of the mind that had also thrilled to Homer 
in ancient Greece - allowed Dickens to transcend the taint of both commercial fiction and "vulgar journalism", but it did so at a cost. ${ }^{10}$

Lisa Rodensky has very usefully mapped the ways the terms "popular" and "folk" were both used by reviewers grappling with Dickens's success in the 1830s: from the outset, preindustrial associations could be used to bypass negative value judgments associated with popular fiction, and to celebrate Dickens's cross-class appeal. ${ }^{11}$ By the 1870 s, as folklorists embraced the "science" of comparative mythology, anthropology found ways of sending Dickens further back in time: not just to pre-industrial England, but to a savage past. In Primitive Culture (1871), the anthropologist Edward Burnett Tylor argued that the primitive had not been eradicated within western civilization: instead, "cultural survivals" lived on. ${ }^{12}$ Influenced by J. F. McLennan as well as Tylor, Lang took up the concept of survivals in his literary criticism. In an essay from 1907, Lang summarized Tylor's contribution to the study of folktale and myth:

Arriving at the old problem of the origins of mythologies, Mr. Tylor [...] took 'savage mythology as a basis', and convincingly proved that mythology is the natural product of the mental condition of savages. Even in Greece, in tales usually left untold or carefully subordinated by Homer, myth retains its savage birth-marks. With this key the old lock is opened, and we understand that the mythical vagaries of gods, and beasts, and men, closely resembling even in minute details the stories of savages, are survivals, repulsive flies caught in the amber of ritual and religion. ${ }^{13}$

For Lang, the similarity of folk tales throughout the world was explained by primitive elements in the psyche that were shared by all humanity: they were not degraded literary myths, but primal tales told by the earliest humans. The comparative method - premised on assumptions that all races climbed, at different rates, up the same ladder of progress -was also 
linked to temporal ways of seeing the mind. While supposedly savage races were deemed to exist in the present, and were constructed as mental echoes of the evolutionary past of Lang's own readers, primitive mental processes and emotions were acknowledged as residual elements in the psychology of the civilized. Lang's defence of romance in his 1887 Contemporary Review article "Realism and Romance" was premised on just this belief: that the civilized mind could still enjoy psychological pleasures that had evolved in earlier developmental stages, and which still dominated the psychology of "barbarian" peoples. Lang conjured up the American realists William Dean Howells and Henry James when he suggested:

Public opinion, in Boston, may condemn us, but we will get all the fun we can out of the ancestral barbarism of our natures. I only wish we had more of it. The Coming Man may be bald, toothless, highly 'cultured,' and addicted to tales of introspective analysis. I don't envy him when he has got rid of that relic of the ape, his hair; those relics of the age of combat, his teeth and nails; that survival of barbarism, his delight in the last battles of Odysseus, Laertes' son. Not for nothing did nature leave us savages under our white skins. ${ }^{14}$

While this is perhaps one of Lang's most cited passages, the critical focus has been placed on the 1890 s "realism and romance" debate, rather than the explicit significance of Homer to Lang's argument. ${ }^{15}$ It was not just fantastic genres that could be recast as a form of ancient romance: the Pickwick Papers, Lang proclaimed, was not a novel at all, but "a modern, humorous Odyssey". ${ }^{16}$

To compare Dickens to Homer was to do more than to celebrate literary genius across time. It was to return to pre-literate psychological origins, to trace the "primitive birth marks" deemed discernable in both. In looking for textual evidence of barbarian customs, myths and 
psychological impulses in the Greek epic, Lang's methodology also depicted the higher literature of Western civilization (like the Western civilized mind itself) as built on a bedrock of elements still prominent in supposedly lower cultures.

When Lang referred to "ancestral barbarism" in "Realism and Romance", he was well aware of its specific meaning in anthropological systems of classification: as the universal, intermediate stage between savagery and civilization through which all peoples were deemed to pass. To associate the enjoyment of Homer with a "survival of barbarism", however, was also to complicate the disciplinary value judgements that read the Greek epic as an unambiguous marker of civilized higher culture.

In Lang's journalism, mass audiences were often psychologically linked to a primitive past. "If we will only be tolerant, we will permit the great public also to delight in our few modern romances and adventures", Lang wrote. "They may be 'savage survivals', but so is the whole poetic way of regarding nature". ${ }^{17}$ Despite Lang's aesthetic defence of the romance, and his physically degenerate (and effeminized) depiction of the lovers of American realism, he did not entirely reject the model of literary evolution propagated by writers including Herbert Spencer, who read literary history as a gauge of progressive moral evolutionary development. ${ }^{18} \mathrm{He}$ did, however, predict that the current celebration of realism would not be the last stage, arguing that moral advance in the future would be compatible with a form of aesthetic return. Lang stated that:

The old barbaric taste will revive and adopt the old forms, which are invariably, and without exception romantic. The future of flat, didactic, and usually affected commonplace is an impossible future. It is Homer and Virgil, or it is fairy tale and myth, that await the world. ${ }^{19}$ 
While Lang was highly critical of the anthropologist Lewis Henry Morgan's theory of kinship relations, he had clearly read his Ancient Society closely. Morgan had predicted both moral progress and a return to some features of barbarian social organisation. ${ }^{20}$ Evolutionary progress was compatible for Lang with the possibility of literary cycles of "recurrence", of an oscillation between tastes for realism and myth. ${ }^{21}$

Lang's adherence to a form of anthropological Romanticism is clearly apparent in his 1907 article on Tylor: here, he argued "without the ideas of the savage (as Keats averred) we should have no poetry worthy of the name", and asserted that the term survival "implied no reproach". ${ }^{22}$ To link the creative faculty to a primitive capacity for mythmaking was to see art itself as a form of mental time travel, in which the civilized mind drew on the imaginative capacity developed during its savage and barbarian pasts.

Lang's psychological universalism had an important function in his writings on Dickens, and in his wider literary sparring with the American realist William Dean Howells. In 1882, Howells's article "Henry James Jnr" in the Century Magazine had caused a stir by championing James at the expense of Dickens and Thackeray. ${ }^{23}$ Howells would subsequently dismiss Dickens's Christmas stories as propagating a "false psychology" manufactured for commercial purposes. Howells regarded Dickens's literary techniques in these texts as infantile, a concession to the demands of "holiday literature". In Criticism and Fiction, Howells wrote:

in those stories of his Dickens said to his readers, let us make believe so-and-so; and the result was a joint juggle, a child's-play, in which the wholesome allegiance to life was lost. Artistically, therefore, the scheme was false, and artistically, therefore, it must perish. It did not perish, however, before it had propagated itself in a whole school of unrealities so ghastly that one can hardly recall without a shudder those 
sentimentalities at secondhand to which holiday literature was abandoned long after the original conjurer had wearied of his performance.

Howells presented Dickens as entirely knowing in his commercial conjuring. True art, Howells asserted, does not "care to paint the marvellous and impossible for the vulgar many, or to sentimentalize and falsify the actual for the vulgar few". ${ }^{24}$ It was not just Howells but Lang who was embarrassed by Dickens's perceived sentimentality, depicting it as an artistic flaw. However, in both his Longman's Magazine columns "At the Sign of the Ship", and his subsequent column in the Illustrated London News, Lang, the self-styled knight of romance, frequently crossed swords with Howells, Harpers' proselytizer for realism: the latter, as Marysa DeMoor has shown, had been significant in Lang's removal from Harper's ${ }^{25}$ The back and forth of their exchanges is apparent in Howells's direct engagement with Lang's argument that romance should be valued for its ability to tap into primitive impulses. Howells accepted a frameworks of cultural evolution in which different literary forms occupied different positions on the ladder of progress. However, he argued that an individual's ability to psychically regress through lower art forms should be seen as a childish impulse, rather than as a marker of literary value. Howells proclaimed:

Many $[\ldots]$ are savage in their tastes, as they show by the decoration of their houses and persons, and by their choice of books and pictures; and these are left to the restraints of public opinion. In fact, no man can be said to be thoroughly civilized or always civilized; the most refined, the most enlightened person has his moods, his moments of barbarism, in which the best, or even the second best, shall not please him. At these times the lettered and the unlettered are alike primitive and their gratifications are of the same simple sort; the highly cultivated person may then like 
melodrama, impossible fiction, and the trapeze as sincerely and thoroughly as a boy of thirteen or a barbarian of any age.

The assumption that literary taste can be evaluated according to a progressive anthropological framework is clearly stated, and the links between class and taste are barely veiled (Howells wrote of the "aesthetical poor whom we will have always with us"). ${ }^{26}$ The enjoyment of popular literature requires a temporary evolutionary descent for the cultured: only then do they join the unlettered, who are imagined as Tylorian survivals, still inhabiting the psychological past of the civilized. It is not just "impossible fiction" but popular culture in general (the trapeze) that is depicted by Howells as a regressive pleasure, appealing to the supposed common psychology of both the "barbarian" and the adolescent boy.

"The vulgar", Howells proclaimed, "do not ask that they shall be quietly made to think and feel, but that they shall be startled; and among the vulgar, of course, I include the great part of those who write literary criticism, and who constitute the worst vulgar, since they teach what they do not know". ${ }^{27}$ While Howells no doubt had Lang directly in his sights, the two critics had more in common than Howells cared to admit: despite their differing aesthetic tastes, the use of anthropological evolutionary stages to measure literary value linked both writers, and the assumed psychological link between the boy and the "barbarian" was also made by both.

For both Lang and Howells, to access the feelings and mental states that characterized childhood was also to remember humanity in its savage beginnings: for Lang, like Herbert Spencer, adhered to the recapitulation thesis, in which children were perceived to pass through ancestral evolutionary stages in their journey towards adulthood. ${ }^{28}$ Lang's attempts to argue for the ancient psychological provenance of romance rejected Howells's value judgments about the commercial vulgarity of fantasy, but he did not question his realist opponent's assumed links between popular culture and psychological and racial childhood. 
This had significant implications for Lang's construction of Dickens's genius. In his introduction to David Copperfield, Lang wrote:

Dickens, as he makes his hero say, had 'as a man a strong memory of my childhood.' This kind of memory seems to be a privilege, or rather a constituent part, of genius. [...] It is probably more than a mere curious fancy which holds that the child re-lives (in a modified way) through the evolutionary experience of the race. To many children, at least, the world is all animated and personal, everything in it has life and character. This is the essence of early human thought $[\ldots]$ But this ancient mood is the indispensable basis of poetry and mythology; this, with the associated difficulty of discerning between dreams and realities.

For Lang, the majority of children have genius: Dickens, along with George Sand, Walter Scott and William Wordsworth, never lost the "gleam" of the "bright visions" of his infancy. ${ }^{29}$ A powerful contribution to the association of Dickens with both childlike genius and Romantic primitivism was the pervasive association of Dickens's novels with critics' own childhood memories. Lang was among those who recorded the transformative effects of the Pickwick Papers as childhood reading. ${ }^{30}$ George Orwell would later reflect on the difficulty of maintaining professional distance when Dickens was closely intertwined with critics' own early psychological histories. "When I say I like Dickens", Orwell mused in 1940, “do I simply mean that I like thinking about my childhood?"31

For Lang, of course, it was not just individual childhood, but the childhood of the race that could be summoned up by reading Dickens, whose own vivid memories of his youth were deemed a psychological portal to the early experiences of mankind. The introduction to David Copperfield offers one of the most obvious examples of the way Lang combined Romantic 
ideas of genius with anthropological constructions of a savage psychic past. In the Gadshill volumes, Lang oscillates between Dickens the late Romantic literary creator, whose genius is his power to creatively summon up his childhood in writing, and Dickens as a kind of shaman, who literally (and unconsciously) embodies that primitive past.

In Lang's Gadshill "General Essay" on Dickens (which reached a wider audience when it was republished in the Fortnightly Review in 1898), Lang drew on his readings in both Spencerian and Tylorian anthropology to suggest Dickens's use of personification was a form of animism. Lang was well versed in these folkloric debates, including Spencer and Tylor's claims that savage humans were unable to distinguish between dreaming and waking selves, and believed in the return of the spirits of dead ancestors. In his translation of The Homeric Hymns, published the same year as the "General Essay", Lang also indicated where he parted company with Tylor and Spencer:

I am not inclined, like them, to accept 'Animism,' or 'The Ghost Theory,' as the master-key to the origin of religion, though Animism is a great tributary stream. To myself it now appears that among the lowest known races we find present a fluid mass of beliefs both high and low.

That the "lowest known races" could show "belief in a moral creative being, a judge of men" as well as in gods that took the form of medicine men or birds, questioned the evolutionist accounts of religion that saw a simple linear development from polytheism to monotheism. ${ }^{32}$ For George W. Stocking, such challenges were part of a turn-of-the-century crisis in anthropology. ${ }^{33}$ Lang's assertion that "high and low" beliefs could intermingle, not just within the supposedly "lowest" races, but within the same mind, could also be disconcerting in terms of established literary hierarchies. In the "General Essay" on Dickens, Lang wrote: 
In the opinion of many philosophers, early man, and simple natural men, and children, regard all nature as animated. [...] Whatever the origin of Animism, thus understood, it is a mark of savage and popular invention, as displayed in myth and fairy tale. Now the early form of human fancy, the form conspicuous amongst backward races, peasants, fishers and children, is undeniably the source of all the civilized poetry and romance. The genius of Dickens was a relapse on the early human intellectual condition. He sees all things in that vivid animated way, and inanimate objects play living parts in his books, more frequently than in any modern works, except Hans Andersen's fairy tales. ${ }^{34}$

There is a clear endorsement of the recapitulation thesis - the modern child whose visions are comparable to those still in the "childhood of the race", reinforcing assertions already made in Lang's introduction to David Copperfield. Lang also draws on the Tylorian concept of cultural survivals, for animism is not just a reality for early humans (in the ancient past) but for "simple natural men" in the present: both "backward races" and those engaged in preindustrial occupations. The familiar equation of Dickens and Andersen with a state of childhood taps into obvious assumptions about class and education - both were frequently valued as representatives of a folk mind rather than as self-conscious literary creators. Yet Lang's alignment of Dickens with "the folk" is complicated by his claim that animism is the source of all the "civilized poetry and romance": that it is a universal survival in the modern mind. Lang claimed:

This manner was perfectly natural to Dickens, who had not, we may presume, reflected much on animism, or the survivals of the primitive in the civilized 
intelligence. But the manner tended to become a mannerism; like all mannerisms it was easily imitated, and degenerated into a weariness. ${ }^{35}$

Once Dickens's literary mannerisms become knowing he resembles Howells's wearied (and wearying) commercial conjuror. It was the Dickens who had not "reflected much" on animism who was valued by Lang as the seer with the capacity for psychic return. To be associated with animism in the 1890 s, however, as Lang was well aware, was not simply to be linked to creativity but to a less positive construction of psychic regression. When Edward Clodd used his Presidential Address to the Folk-Lore Society in 1895 to accuse psychic researchers of abandoning scientific detachment, Lang (who would become president of the Society for Psychical Research in 1912) responded with his own "Protest of a PsychoFolklorist". "Every province of the Psychical Society's labour appears to be regarded by Mr. Clodd as vitiated by 'the old animism' in disguise", Lang lamented, "and therefore as nonsense and superstition". ${ }^{36}$

These debates within folklore and anthropology undoubtedly informed Lang's reflections on animism, hallucination and genius in the Gadshill Dickens. In "Adventures Among Books", first published in Scribner's Magazine (1891), Lang attempted to advocate for the study of folklore by claiming it could capture the evolution of culture and morals, and also illuminate the relationship between individual genius and collective tradition. Acknowledging his debts to J. F. McLennan, Lang wrote:

The topic of folklore, and the development of custom and myths, is not generally attractive, to be sure. Only a few people seem interested in that spectacle, so full of surprises - the development of all human institutions, from fairy tales to democracy. In beholding it we learn how we owe all things, humanly speaking, to the people and to genius. The natural people, the folk, has supplied us, in its unconscious way, with 
the stuff of all our poetry, law, ritual: and genius has selected from the mass, has turned customs into codes, nursery tales into romance, myth into science, ballad into epic, magic mummery into gorgeous ritual. ${ }^{37}$

For Lang, Dickens's “native naked genius" appears to occupy a third position: for it is closer to genius when it is seen as a psychological exemplar of "the natural people, the folk". ${ }^{38}$ It is significant that the latter can only supply material for art "in its unconscious way". In a decade of near universal literacy, the most persistent myth of all was that of "the folk", still characterized by an unconscious creativity that placed them psychologically in the pre-literate past.

For R. R. Marett, who would become E. B. Tylor's successor in anthropology at Oxford University, Lang was one of the pioneering scholars who sought to unite anthropology and the classics, shaping (along with Marett himself) a bold new interdisciplinary field. In his 1917 address as outgoing president of the Folk-Lore Society, Marett echoed some of Lang's earlier assertions with his own concepts of "transvaluation" and "devulgarization". It was certain, Marett argued, that "the unconscious art of the folk can develop into art of the conscious and refined order, and must do so if the latter is to be truly national in type". However, this process of "devulgarization" involved both technical and ethical intervention: the "constructive genius re-adapts the rude material conformably to some high moral purpose". 39

Marett acknowledged that the change of value accorded to a cultural practice ("transvaluation") could occur on the "horizontal" plane (as when religious practices lost their ritualistic meanings, passing into art) as well as involving an upward or downward cultural movement. Marett's description of the "constructive genius", however, was still linked to higher culture: folklore, though clearly worthy of study, was imagined (like childhood) as a 
subterranean psychological realm. In the "underworld of folklore the prevailing movement is downhill”, wrote Marett, arguing that the process of readaptation in this realm was always "subconscious". "Conscious renovation" was deemed to occur "only at a higher level of culture", and indeed became one of its defining features. ${ }^{40}$

The complexity of defining cultural value across disciplines was all too apparent when Lang, who had held a Fellowship in Classics at Merton College from 1868-75, joined Marett and other Oxford academics to lecture on "Anthropology and the Classics" in 1908. In his introduction to the published lectures, Marett revealed that the cultural hierarchies that Tylor (then still Chair of Anthropology at Oxford), had helped to cement were still very much in place. Marett argued that "the types of human culture are, in fact, reducible to two, a simpler and a more complex, or, as we are wont to say (valuing our own achievements, I doubt not, rightly), a lower and a higher". Arguing that anthropology conventionally "occupies itself solely with culture of the simpler or lower kind", while the Humanities, with "their parent source in the literatures of Greece and Rome" concentrate on "the higher life of society", he nevertheless reflected on a conundrum:

What, then, of phenomena of transition? Are they to be suffered to form a no-man'sland, a buffer-tract left purposely undeveloped, lest, forsooth, the associates of barbarism should fall foul of the friends of civilization? Plainly, in the cause of science, a pacific penetration must be tolerated, nay, encouraged, from both sides at once. Anthropology must cast forwards, the Humanities cast back. ${ }^{41}$

Lang had certainly psychologically "cast back" in his writing on Dickens, a modern writer discussed in terms that placed him in a "buffer zone" between the supposedly unconscious creativity of lower cultures ("barbarians" and "the folk") and the literary genius that was linked to higher culture. While Marett assumed progressive social evolution towards Lecky's 
"European epoch of the human mind", Lang's own Oxford lecture on "Homer and Anthropology" intentionally merged present and ancient past when discussing the creative faculty:

No early poet, perhaps no poet, can avoid, in religion and myth, barbaric and savage survivals, owing to the nature of the legendary materials on which his works are based. Nobody, we may almost say, invents a plot: all borrow from the huge store of world-wide primaeval Märchen, or folk-tales. ${ }^{42}$

If "barbaric survivals" can be traced in the language of all poets, then anthropology might help to unlock all literature, through the common stores of myth deemed to exist in the civilized mind itself. The influence of Frederic W. H. Myers's work in mental science is clearly apparent in Lang's own later writings on creativity. One of the founding members of the Society for Psychical Research (and originator of the term telepathy), Myers stoked controversy amongst folklorists by suggesting that "savage" peoples were not simply deluded: trance states, dreams and hallucinations were the product of a subconscious or "subliminal" mind which could potentially make contact with a spiritual realm. Rather than seeing the eradication of survivals as a sign of progress, Myers, in his essay "Greek Oracles", argued for something more complex:

On behalf of savages, and our ancestors in general there may be room for some apology. If we reflect how large a part of human knowledge consists of human emotion, we may even say that they possessed some forms of knowledge which we have since lost [...] The child's vivid sensibility, reflected in his vivifying imagination, is as veritably an inlet of truth as if it were an added clearness of physical vision. Now, in this way too, the savage is a kind of child; his beliefs are not always to be 
summarily referred to his ignorance; there may be something in them which we must realise in imagination before we venture to explain it away. ${ }^{43}$

Myers's assertions were clearly premised on Romantic and anthropological readings of the recapitulation thesis, which conflated the psychology of "savages" and children. Lang recommended a number of Myers's works in his entry on "Psychical Research" for the Enclopaedia Brittanica in 1911, including this essay on oracles. In his 1907 essay on Tylor, Lang referenced Myers to emphasize not what had been lost, but the continuing psychological resemblances between the civilized European mind and its earliest known human ancestors:

Homo, in the earliest stage at which we make his acquaintance, is already the philosopher, artist, and man. [...] we have scarcely a theory concerning the deeper problems of life which savage man has not already invented in his mythical Platonic way $[\ldots]$. his ghosts are our phantasms $[\ldots]$ We cannot escape from him in any field of activity; we repeat his theories without knowing; or knowingly, as when Mr. F. W. H. Myers boldly proclaimed his own reversion to "palaeolithic psychology. ${ }^{, 44}$

Myers used the term "palaeolithic psychology" in the posthumously published The Human Personality and its Survival of Bodily Death (1903) to describe "the habits of thought of the savage who believes he can travel in dreams". ${ }^{45}$ Lang's Tylor is rather closer to Myers than Tylor himself would have perhaps have found comfortable, for in Primitive Culture in 1871 Tylor wrote of modern spiritualism as a savage "survival" that had "burst out afresh" as a form of "revival". If such beliefs were clearly deemed regressive by Tylor, his speculative style had also placed the enlightenment values to which he pledged allegiance under scrutiny. Tylor wrote:

The issue raised by the comparison of savage, barbaric, and civilized spiritualism, is 
this: Do the Red Indian medicine-man, the Tatar necromancer, the Highland ghostseer, and the Boston medium, share the possession of belief and knowledge of the highest truth and import, which, nevertheless, the great intellectual movement of the last two centuries has simply thrown aside as worthless? Is what we are habitually boasting of and calling new enlightenment, then, in fact a decay of knowledge? ${ }^{46}$

If Tylor's researches directed his readers towards a clear no, Myers was willing to consider a qualified yes. Lang's own view was that the psychic phenomena left "hanging" by Tylor in

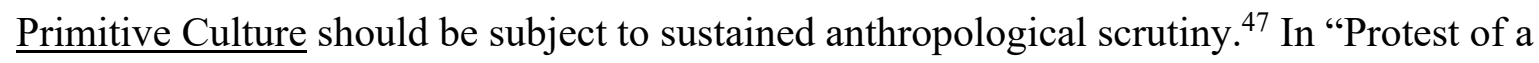
Psycho-Folklorist", Lang wrote that hallucination and telepathy, like "hypnogogic states" (including lucid dreaming), were not signs of individual pathology; nor were they necessarily proof of ghostly return. Rather, they were normal mental experiences shared by a minority across all cultures and time periods, which mythology revealed to have been present since the early evolution of humanity. ${ }^{48}$

Lang's awareness in the 1890 s of his own complex status within emerging disciplines deemed pioneering by some anthropologists, classicists and folklorists, regarded by others as a deluded defender (or even practitioner) of savage beliefs - sheds new light on his introductions to the Gadshill Dickens. ${ }^{49}$ In the "General Essay" in the final volume, Lang linked Dickens's visionary genius explicitly to those debates within folklore, mental science and psychic research:

Dickens himself leaves it certain that his imagination, at certain times, went back to what is probably the primitive condition of actual hallucination. His dreams sometimes seemed to slip the bond of time and become actually premonitory. At other times, he himself could not say if the dream was onar or hupar, in Homeric phrase an illusion of sleep or a waking vision. All this side of genius, all its manifestations 
and experiences of the 'subliminal' or sub-conscious self, form a topic hitherto very little studied, but obviously deserving of the care of psychologists. ${ }^{50}$

Here, Homer gives cultural prestige not only to Dickens, but also to the anthropological investigation of hallucination and psychic research, as well as to mental science's broader interests in the subconscious. Lang's casual invocation of knowledge gained as an Oxford classicist when engaging with these newer fields was a calculated strategy. If the use of Homeric terms makes the case for the long historical continuity of such mental phenomena, Myers (a former Cambridge classicist) had also turned to the Greek in coining the term "telepathy". ${ }^{51}$ It is notable that Lang makes use of Myers's preferred term, "subliminal consciousness", as well as the now more recognizable "sub-conscious" to refer to mental phenomena below the threshold of conscious thought. While Myers imagined different strata of the mind through temporal and geological metaphors - the "clay" that underpins the "gravel" of consciousness - these layers were also deemed to be permeable. In an 1893 article for the Nineteenth Century, Myers claimed "the 'genius' shown in discovery or creative art may be defined as an 'uprush of subliminal faculty"'. In an 1886 article in the same magazine, he had argued that the "hypnotic trance" could be classified as a "higher" mental state, with analogies to genius as well as to hysteria. ${ }^{52}$

Lang's criticism of Dickens reveals the influence of Myers's work on creativity, which linked the mythmaking capacity to the subliminal mind and suggested genius could operate on survivals lurking in mysterious regions of the civilized consciousness. In his later article "Greek Oracles", Myers argued that the poetic genius of Homer also drew on his own psychological reservoir of barbarism:

the descent of Odysseus to the underworld, 'to consult the soul of the Theban Teiresias,' shows in a way which it would be hard to parallel elsewhere the possible 
co-existence in the same mind of the creed and practices of the lowest races with a majesty, a pathos, a power, which human genius has never yet overpassed. The eleventh book of the Odyssey is steeped in the Animism of barbarous peoples. ${ }^{53}$

The ambiguity of Dickens's genius for the psycho-folklorist was in part due to those tensions in the construction of the subconscious: both valorized as a source of creative inspiration, and conceived as originating in a savage past which was still deemed to dominate the minds of "lower" peoples.

That Dickens was fascinated with mesmerism, and claimed to John Forster that he saw rather than invented his characters, was an obvious gift to the practitioner of psychofolklore ${ }^{54}$ In fact, it had already been seized upon by earlier critics who were beginning to meld literary criticism with a nascent evolutionary psychology. The use of such methods by Hippolyte Taine, George Henry Lewes and Walter Bagehot began to reshape debates over Dickens's genius before the writings of Lang and Myers: they were central to the debate (to use Rosemarie Bodenheimer's terms) over "what Dickens knew" 55 . Bagehot, in constructing Dickens as an "asymmetrical" genius, emphasized vision rather than cognitive reflection: Dickens's memory was deemed capable of picturing every object in a street. If the term “infantile” appears several times in Bagehot's account of Dickens's genius, Lang would later refer to genius as a form of intuition commonly experienced by children. "“Intuition' means 'seeing", he wrote, "and it will be found that persons of genius do see in their mind's eye [...] with a clearness unfamiliar to the general body of mankind". ${ }^{56}$

G. H. Lewes's writing on Dickens in the 1870s was, as Peter Melville Logan has shown, also built on an evolutionary framework, influenced by Comtean Positivism: Lewes, Logan argues, turned to a mode of "primitive criticism" in his own attempted defence of Dickens as a popular writer. The link between Lewes and Lang, I would argue, is the turn to models of psychological and cultural evolution to sidestep accusations of Dickens's literary vulgarity, an 
aim openly articulated by Lewes before it was taken up by Lang. ${ }^{57}$ By the 1890 s, the visionary Dickens already had a critical history. It would be a mistake, then, to see Freud and Jung as the sole originators of psychoanalytic approaches to Dickens: Lang's psycho-folklore built on a nascent tradition of literary anthropology, which has a longer and richer interdisciplinary history. The tendency in Dickens scholarship to critically engage with Lewes rather than Lang, however, has tended to obscure the latter's influence.

Constructions of Lang as the hearty anti-decadent critic have been tenacious, but they tell only half the story. "These excesses of Pickwickians are to be taken in a Pickwickian sense; they are as symbolical as Maeterlinck, and infinitely more entertaining” Lang wrote in his “General Essay" on Dickens in 1898. ${ }^{58}$ While Lang compared Dickens's works favourably to those of a Belgian symbolist, he was also willing to flirt with symbolist definitions of romance: as "that element which gives a sudden sense of the strangeness and the beauty of life; that power which has the gift of dreams". ${ }^{59}$ Such proclamations place Lang rather closer to an understanding of the practice of a literary avant-garde than Hubbard suggests when he argues "modern trends in the reception of literature were passing him by". ${ }^{60}$

Arthur Machen's affiliations with decadence and symbolism made him more, not less receptive to psycho-folklore: for Machen, the Pickwick Papers was both a latter-day Odyssey, and the embodiment of ancient ritual. In a suggestive article, Christine Ferguson has referred to Machen and his fellow occultist E. A. Waite as initiators of the "ecstatic" mode of reading: both, she convincingly argues, used Pickwick as a portal to a numinous spiritual realm. ${ }^{61} \mathrm{I}$ would argue, however, that this was far from an isolated literary trend: Myers had previously suggested ecstatic psychological states should be analysed for the insights they offered into a spiritual reality that co-exited alongside the material. The ecstatic reading of Pickwick has roots not just in Myers, but in the psycho-folklore of Lang, with which Machen was well acquainted. In Machen's late short story “The Dover Road” (1936), Lang’s credentials as an 
investigator of hauntings were used as a corroborating narrative flourish, in a knowing tale that also referenced Dickens's “The Haunted House”. In The Great Return (1915), Machen referenced Lang twice and gave credulity to psycho-folkloric assumptions that myth exists in uncharted regions of the mind. He credited "the possible survival of old tradition in a kind of dormant, or torpid, semi-conscious state". ${ }^{62}$

In the imagined dialogue of Machen's Hieroglyphics (1902), Mr Pickwick's tavern visits become comparable to trance states: they offer (like all true art for Machen) a retreat from the "common ways of life". The narrator wonders aloud "was Dickens aware that by milk-punch he meant ecstasy?" His answer reveals the influence of both Myers and Lang:

I said that to answer the riddle fully and completely one would have to make an analysis of human nature; and, in truth, the problem is simply a problem of the consciousness and subconsciousness, and of the action and interaction between the two. I will not be too dogmatic. We are in misty, uncertain and unexplored regions [...] but I am strangely inclined to think that all the quintessence of art is distilled from the subconscious and not from the conscious self; or, in other words, that the artificer seldom or never understands the ends and designs and spirit of the artist. ${ }^{63}$

Machen, like Lang, had been a reader of Myers, Gurney and Barratt's Phantasms of the Living. In linking Pickwick to both the Odyssey and the cult of Aphrodite and to Baccus, Machen united anthropology with symbolist practice: the true reader of Dickens was not only a Paterian adept, acutely sensitive to subjective impression, but delved into the ancestral folk mind as a way of accessing that "misty" spiritual realm. Pickwick was used to show up the limitations of the kind of realism celebrated by Howells: there was, Machen wrote, "the voice which tells us distinctly that man is not the creature of the drawing-room and the Stock Exchange, but a lonely awful soul confronted by the Source of all Souls". Machen's 
evaluation of literature (including Pickwick) according to whether it has a right to "stand on the Odyssey shelf" seeks to place Dickens in Machen's own idiosyncratic canon of high literature. As late as 1941, Machen referenced one of Lang's articles on Dickens, and continued to link Dickens to Homer. "Mr Pickwick was a retired man of business, who had wound up his affairs in the year 1827: but he is of the race of Ulysses", Machen wrote. Greek epic, for this former Hereford Cathedral schoolboy, remained an unquestionable marker of literary value. ${ }^{64}$

To generate spiritual visions through the reading of Pickwick was to take Lang's own literary anthropology to a new level, but it still drew on the comparative method's exhilarating promise of psychically and emotionally communing with the past. If Machen claimed true art was informed by "subconscious" Catholicism (interpreted as a reading of spiritual symbols, whether Christian iconography or the "initiatory dance of savages"), a more conscious kind was at the heart of G. K. Chesterton's reading of Dickens a few years later. ${ }^{65}$ He, too, sought to distance Dickens from contemporary realism and claim him for folklore (and a demotically constructed "folk"):

Our modern novels, which deal with men as they are, are chiefly produced by a small and educated section of society. But this other literature deals with men greater than they are - with demi-gods and heroes; and that is far too important a matter to be trusted to the educated classes. ${ }^{66}$

Machen's Bacchanalian Pickwick Papers was in fact surprisingly close to the anti-decadent Chesterton's: both encouraged the reading of spiritual symbols. For Chesterton Pickwick comes to symbolize "the tavern at the end of the world", the final destination for the human soul; Machen was convinced that Dickens "knew the great everlasting book had a happy 
ending" ${ }^{67}$ It was not just an interest in reading spiritual symbols, but a mutual interest in Lang's psycho-folklore that united both.

In his conclusion to his 1906 critical study of Dickens, Chesterton wrote of his relief at the perceived end of literary decadence. "The hour of absinthe is over. We shall not be much further troubled with the little artists who found Dickens too sane for their sorrows and too clean for their delights". ${ }^{68}$ Yet, like Chesterton, decadent writers also created a Dickens cut loose from authorial intention, whose works were deemed to awaken impulses deep in the mind, body or soul of the reader. Chesterton conveniently overlooked Des Esseintes in J. K. Huysman's novel À Rebours (1884), who found it was not erotica, but Dickens's chaste fictions that could reawaken his flagging libido. In Huysman's novel, Dickens's books are also linked to a form of literary trance. Through Des Esseintes' reading of Dickens's novels, the Bodega in Paris is transformed into Victorian England, a literary hallucination that is so powerful and satisfying that the protagonist abandons his planned pilgrimage to London altogether. ${ }^{69}$ Machen is known to have read Huysmans's novel, and Huysmans and well as Lang, Myers and Waite paved the way for Machen's construction of the Pickwick Papers as source material for both the symbolist and seer. ${ }^{70}$

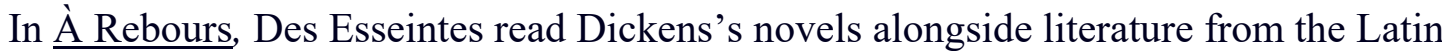
decadence. Chesterton's desire to annihilate literary time was surprisingly similar:

If Our Mutual Friend was written in the Latin of the Dark Ages we should still want it translated. If we thought that Nicholas Nickleby would not be written until thirty years hence we should all wait for it eagerly. The general impression produced by Dickens's work is the same as that produced by miraculous visions; it is the destruction of time.

Chesterton argued that Dickens's books (except Sketches by Boz, linked to "vulgar journalism") could actually be read backwards, or by opening pages at random: "this is not 
chaos" he asserted, "it is eternity" ${ }^{71}$ Machen would later make the same case, arguing that Dickens's novels should be constructed from juxtapositions of passages compiled by each reader - his best books, Machen maintained, were those Dickens had not written at all. ${ }^{72}$ In this mode of criticism, no plots (as Lang had claimed) are new, and all readers draw on their common psychic ancestry to become storytellers and mythmakers.

While Machen constructed all creativity as unconscious, to read Dickens as revealing the survival of savage animism, or a folk mind, was still to give him an equivocal place in modern literary tradition. His value was explicitly his distance from modernity. That the folk past could be rendered as highly contradictory - primitive, cruel yet imbued by a Romantic nostalgia - is clearly apparent in Lang's writings on Dickens. In his Letters to Dead Authors, Lang addressed Dickens directly:

From the old giants of English fun - burly persons delighting in broad caricature, in decided colours, in cockney jokes, in swashing blows at the more prominent and obvious human follies - from these you derived the splendid high spirits and unhesitating mirth of your earlier works. Mr. Squeers, and Sam Weller, and Mrs. Gamp, and all the Pickwickians, and Mr. Dowlet, and John Browdie - these and their immortal companions were reared, so to speak, on the beef and beer of that naughty, fox-hunting, badger-baiting old England, which we have improved out of existence. And these characters, assuredly, are your best; by them, though stupid people cannot read about them, you will live while there is a laugh left among us. Perhaps that does not assure you a very prolonged existence, but only the future can show. ${ }^{73}$ 
It is hard to imagine a more double-edged celebration. While the loss of the folk spirit of "that naughty, fox-hunting [...] old England" anticipates G.K. Chesterton's celebration of Dickens as the "last cry of Merrie England", that loss, Lang is at pains to point out, is also the loss of the casual cruelty of the gibbet, "the pillory and the stocks": it is part of the inevitable moral evolution, as Lang termed it, "from fairy tales to democracy". If folk humour is deemed to live on, submerged in the common psyche, there is a clear tension here between Lang's psychic universalism and literary judgements: the Pickwickians may be immortal, but not to "stupid people". Lang's attempts to link Dickens to folk archetypes - "old giants of English fun" - also leads to difficulty in interpreting their moral value, as either cultural survivals of a cruel but humorous past, or timeless embodiments of folk justice. At some points, Dickens is clearly aligned by Lang with the latter: "his heart, his mirth, his observation, his delightful high spirits, his intrepid loathing of wrong, his chivalrous desire to right it, - these things will make him forever, we hope and believe, the darling of the English people", he wrote in an article for Good Words. ${ }^{74}$

In Lang and S. H. Butcher's English translation of the Odyssey (still compulsory reading, as Cyril Connolly wryly remembered, for Eton schoolboys in the early 1920s), the translators made clear that they were working on the premise that popular folktales preceded the epic. The unifying genius of Homer, as they perceived it, was to work with an inherited "tissue of old marchen" so "that the marvels of savage and barbaric fancy become indispensible parts of an artistic whole". ${ }^{75}$ In this construction, primitive mythmaking throbs beneath the greatest works of literary genius. Using a revealing metaphor reminiscent of Spencer, Marett argued in 1917 that Tylor had not been prey to the "false psychology" that treats "a survival as mere inert matter, a waste product passively impeding the exercise or organic function" ${ }^{76}$ If folk culture was no longer being imagined as human waste, and was instead being reclaimed as a living psychological reality, some minds were still deemed more advanced than others. Even 
in the early twentieth century, those assumptions that "savages", "barbarians" children, the rural (and sometimes the urban) working class were psychically linked to earlier developmental stages were difficult to dispel.

The construction of Dickens as psycho-folkloric subject rehabilitated him from pejorative associations with cheap popular culture, which included the journalism that was central to the careers of Dickens, Lang, and Chesterton alike. In 1911, Chesterton had been troubled by the perceived closeness of Dickens's humor to that of contemporary popular ephemera. "It is quite true that his jokes are often on the same subjects as the jokes in a halfpenny comic paper”, he asserted, “only they happen to be good jokes”. Dickens's use of stock subjects was not vulgar: in fact, Chesterton announced:

all the more because they are stock subjects the reader realises what a magician is at work. The notion of a clumsy fellow who falls off his horse is indeed a stock and stale subject. But Mr. Winkle is not a stock and stale subject. Nor is his horse a stock and stale subject; it is as immortal as the horses of Achilles. The notion of a fat old gentleman proud of his legs might easily be vulgar. But Mr. Pickwick proud of his legs is not vulgar; somehow we feel that they were legs to be proud of. ${ }^{77}$

Chesterton, who read Lang's books at a "fairly early age", claimed that he had "revolutionised anthropology": he also saw him as one of the "ablest literary critics of our time" ${ }^{78}$ Here, the influence of Lang's innovations in both fields are apparent: Chesterton uses Homer to negotiate a cultural place for Dickens that sets him apart from the comic strip and the music hall. In his 1909 article on George Meredith, Edward Clodd had cited Meredith's casual dismissal of Dickens as “the incarnation of cockneydom”. In light of Meredith's assertions that "the world will never let Mr. Pickwick, who to me is full of the lumber of imbecility, 
share honours with Don Quixote", the psycho-folkloric claims of Lang, Chesterton and Machen posed an explicit challenge to the vulgar Dickens: in their world he proudly shared honours with Homer. ${ }^{79}$

In his supporting essay to his translation of Homeric Hymns (1899) Lang referred to Greek myth as shaped by barbarism, and referenced his own use of the comparative method in his classical scholarship:

Till the end of the present century, mythologists did not usually employ the method of comparing Greek rites and legends with, first, the sympathetic magic and the fables of peasant folk-lore; second, with the Mysteries and myths of contemporary savage races, of which European folk-lore is mainly a survival. ${ }^{80}$

To read the classics in conjunction with European folktales and tribal myths was to find striking points of resemblance as well as difference between the supposedly highest and lowest cultures. To read popular nineteenth-century fiction in terms of its resemblance to all three was to enact a critical form of devulgarization, turning the Dickensian novel into a form of folkloric survival.

In his Presidential Address to the Folk-Lore Society in 1917, “The Psychology of CultureContact", Marett noted that that the meaning of the term "folklore" had shifted during the 1870s under the influence of Lang and Tylorian anthropology:

It is true that, when William Thoms gave the word to the world in 1846, he was content to assign to his 'good Saxon compound' the broad and comfortable meaning of 'the lore of the people'. But already the same year as saw the first general meeting of this society Andrew Lang had roundly defined folklore as 'the study of survivals'. ${ }^{81}$ 
The assumption that folklore was only worth studying if seen as a remnant of the past was implicit in the second definition. Marett would note the attributing of value within "higher" culture when popular practices moved from the sphere of living ritual to "ornament": the folksong and folklore revivals might themselves be read as devulgarizing projects in these terms. Marett was aware, too, that even in the twentieth century, folklorists sometimes still felt the need to justify their object of study: their interest, as Marett put it, in "the sayings and doings of those whom Hume had defined as "the lowest vulgar". ${ }^{82}$ To see folk culture as a survival that could help to explicate cultural evolution was to give folklore scholarship scientific prestige. To see nineteenth-century popular literature as rooted in preliterate and subconscious realms was to justify its value on the same terms: a move that was simultaneously both infantilising and devulgarizing.

The ambitious interdisciplinary aspirations of both Lang and Marett - to unite the methodologies of anthropology, the classics, and folklore - also revealed tensions in their constructions of higher and lower culture. Marett noted that inverted commas had been used around the word culture by Lang and the early members of the Folk-Lore Society, for culture as a unique and conscious possession of "higher" peoples, the civilized, and culture as a set of social practices witnessed amongst those constructed as savages and barbarians were concepts which the early folklorists sometimes struggled to align.

Marett and Lang often constructed "the folk" as less conscious than their anthropological interpreters, or the literary geniuses (such as Homer) who were deemed to transmute their rude lore into high art. Yet Marett also repeated the assertions of Tylor and Lang that "savage impulses" could lay "dormant in the heart of civilised man": he was careful in Psychology and Folk-Lore to point out that it was not just "savage" minds, but all minds that could sometimes act without true consciousness of the "springs of action". ${ }^{83}$ For Marett, as for 
Howells, Lang, and Myers, the meeting of "higher" and "lower" took place, not simply in an external realm of cultural contact, but within the most civilized European mind.

It was Lang's ability to move, not merely between disciplines, but between academic and popular audiences that made him particularly attuned to the academic values by which popular literature was still judged. He noted drily that:

the ancient classics have a value for which there is no substitute. There is a charm in finding ourselves - our common humanity, our puzzles, our cares, our joys, in the writings of men severed from us by race, religion, speech, and half the gulf of historical time - which no other literary pleasure can equal. Then there is to be added, as the university preacher observed, 'the pleasure of despising our fellow-creatures who do not know Greek.' ${ }^{84}$

To read Dickens the nineteenth-century novelist across an historical gulf that did not actually exist clearly failed to acknowledge his modernity, but it also exposed some of the values still implicit in debates about taste and literary value. Sebastian Lecourt is right to argue that Lang's "actual populist practice was undercut by a cult of lost Romantic authenticity" ${ }^{85}$ Yet, for all his Romantic reflections on a mythologized folk, Lang could also show sensitivity to the cultural gatekeeping that devalued the literary knowledge of working-class readers. "To know Shakespeare by heart is as rare in Universities as it is in railway-works and factories", he observed in the Cornhill Magazine in $1901 .{ }^{86}$ In an article for the magazine the same year, "Examinations in Fiction", Lang referenced a mid-century Oxford in-joke: a publication by two dons, The Student's Guide to the School of Literae Ficticiae (1855) that had set questions about modern fiction (including Dickens's novels) modeled in the style of an Oxbridge classics paper ${ }^{87}$ When a similar Cambridge spoof, Stuart Calverley’s 1857 exam on the 


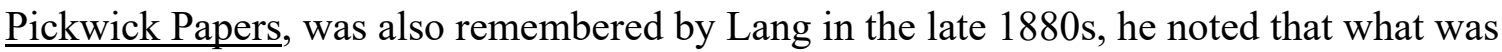
once popular was now arcane knowledge: few readers, Lang mused, would now pass Calverley's paper. Dickens in Lang's account has been thoroughly devulgarized: "when $\mathrm{Mr}$ Pickwick's Adventures are presented to the modern maid", Lang claimed, "she behaves like the Cambridge freshman" fleeing from Euclid: ${ }^{88}$ In 1901, the prospect of Oxford establishing "a tripos, or school, of fiction", the Bodleian becoming home to circulating library novels, and the university press publishing fiction was gently mocked by Lang. ${ }^{89}$ Yet by using his own Oxford credentials to place Dickens “on the Homer shelf”, Lang the psycho-folklorist had already played a role in the legitimization of popular fiction as a scholarly field.

${ }^{1}$ Lang, “Protest of a Psycho-Folklorist,” Folklore, 6.3 (1895): 242.

${ }^{2}$ It is surprising these volumes are largely overlooked. In the 1970s, Joseph Weintraub gave some attention to Lang's Fortnightly Review article (reprinted from the Gadshill “General Essay") in “Andrew Lang: Critic of Romance," ELT 18:1 (1975): 5-15. Extracts from two of the Gadshill introductions are reprinted in The Selected Writings of Andrew Lang, ed. Tom Hubbard, 3 vol. (Routledge: 2017), 3: 30-44. While this is welcome, Hubbard's headnotes tend to dismiss their critical significance.

3 Carl Jung used this term in 1916 in Collected Papers on Analytical Philosophy. In The Structure and Dynamics of the Psyche he wrote "The collective unconscious - so far as we can say anything about it at all - appears to consist of mythological motifs or primordial images, for which the myths of all nations are its real exponents." Arguing that we can "study the collective unconscious in two ways, either in mythology or in the study of the individual", Jung's claims echo those made by Lang for psycho-folklore. See 
C. J. Jung, Collected Works, ed. Gerhard Adler, Michael Fordham and Herbert Read, 20 vol. (London: Routledge: 2015), 8: 3108-109.

${ }^{4}$ G. K. Chesterton, Charles Dickens: A Critical Study (New York: Dodd Mead, 1906), 83.

5 On Lang's perceived amateurism, see Julia Reid, “'King Romance' in Longman's Magazine: Andrew Lang and Literary Populism," Victorian Periodicals Review 44: 4 (2011): 354-55 and Leigh Wilson, “There the Facts Are': Andrew Lang, Facts and Fantasy," Journal of Literature and Science 6:2 (2013): 29.

${ }^{6}$ Lang, Old Friends: Essays in Epistolary Parody (London: Longman's Green, 1890), 26.

${ }^{7}$ Susan Bernstein and Elsie Michie, eds, Victorian Vulgarity: Taste in Verbal and Visual Culture (London: Routledge, 2009), 2. James Buzard's “Wulgarity and Witality: Making a Spectacle of oneself in Pickwick" (Victorian Vulgarity, 35-54) focuses on internal tensions in the text rather than examining criticism.

8 George Gissing, Charles Dickens: A Critical Study (New York: Dodd, Mead, 1898), 241. See also Gissing's The Immortal Dickens (London: Cecil Palmer, 1925), which reproduces Gissing's introductions to the Methuen Rochester edition of Dickens, and makes the same point.

${ }^{9}$ Chesterton, Appreciations and Criticisms of the Works of Charles Dickens (London: Dent 1911), viii, 209. Chesterton noted that these pieces were first published as introductions to a cheap edition of Dickens's works (vii). 10 The phrase is Chesterton's: see Appreciations, 4.

${ }^{11}$ See Lisa Rodensky, “Popular Dickens,” Victorian Literature and Culture 37 (2009): 583-607. 
12 Edward Burnett Tylor, Primitive Culture: Researches into the Development of Mythology, Philosophy, Religion, Language, Art and Custom, $6^{\text {th }}$ edn (London: John Murray, 1920), 70-112.

13 Lang, "Edward Burnett Tylor," in Anthropological Essays Presented to Edward Burnett Tylor in Honour of his 75th Birthday, H. Balfour and others (Oxford: Clarendon, 1907), 9.

${ }^{14}$ Lang, “Realism and Romance,” Contemporary Review 52 (1887): 689.

${ }^{15}$ See, for example, Reid, Christine Ferguson, Language, Science and Popular Fiction in the Victorian fin de Siècle (London: Routledge 2006), 55-57, and Anna Vaninskaya, William Morris and the Idea of Community: Romance, History and Propaganda (Edinburgh: Edinburgh University Press, 2010), 26-27. ${ }^{16}$ Lang, "Introduction," in The Personal History of David Copperfield. Gadshill Edition of the Works of Charles Dickens, 34 vol. (London: Chapman and Hall, 1898-99), 14: vii. 17 Lang, “Realism and Romance," 690.

${ }^{18}$ Herbert Spencer, The Principles of Psychology 4th edn, 2 vol. (London: Williams and Norgate, 1899), 2: 714.

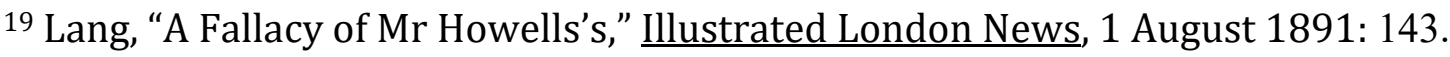

20 On Morgan and barbarism, see Caroline Sumpter, "Anthropology, Socialist Prediction and William Morris's $\underline{\text { Commonweal", }}$ Social and Cultural History 9:3 (2012): 349-367. ${ }^{21}$ Lang, “Examinations in Fiction,” Cornhill Magazine 10 (1901): 86. ${ }^{22}$ Lang, "Tylor", 17.

${ }^{23}$ See Michael Anesko, Letters, Fictions, Lives: Henry James and William Dean Howells (Oxford: Oxford University Press), 236-37.

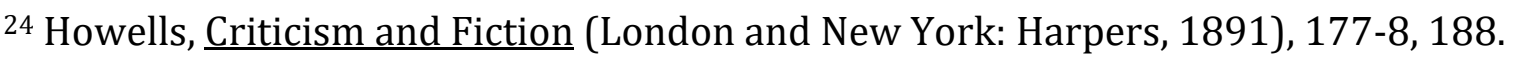


25 See Marysa DeMoor, “Andrew Lang versus W. D. Howells: A Late-Victorian Literary Duel," Journal of American Studies, 21:3 (1987): 416-22.

${ }^{26}$ Howells, Criticism, 109, 181.

27 Howells, Criticism, 66.

${ }^{28}$ On recapitulation see Stephen Jay Gould, The Mismeasure of Man (New York: Norton, 1996), 141-52, Sally Shuttleworth, The Mind of the Child (Oxford: OUP, 2010), 4, 39, 269. On the Romantic child and recapitulation, see Sumpter, The Victorian Press and the Fairy Tale (Aldershot: Palgrave Macmillan, 2008), 39-46.

${ }^{29}$ Lang, "Introduction," in David Copperfield, vii.

30 Lang, Adventures among Books (London: Longmans, Green, 1905), 10.

${ }^{31}$ Orwell, "Dickens", in Inside the Whale and Other Essays (London: Victor Gollancz, 1940), 66.

${ }^{32}$ Lang, The Homeric Hymns: A New Prose Translation, and Essays Literary and Mythological (London: George Allen, 1899), 22.

${ }^{33}$ George W. Stocking, The Ethnographer's Magic and other Essays in the History of Anthropology (Wisconsin: University of Wisconsin Press, 1992), 38.

${ }^{34}$ Lang, "General Essay on the Works of Charles Dickens," in Reprinted Pieces. Gadshill Dickens, 34: ix-xxxv.

35 Lang, “General Essay,” xvi.

${ }^{36}$ Lang, "Protest of a Psycho-Folklorist,": 237.

${ }^{37}$ Lang, Adventures, 10. Robert Michalski in "Towards a Popular Culture: Andrew Lang's Anthropological and Literary Criticism," Journal of American Culture 18.3 (1995): 13-15 reads this passage as legitimating "the role of 'the people' in the production of culture," but does not engage with the unconscious nature of that enterprise. 
38 Lang, “Dickens," republished in Essays in Little (New York: Scribners, 1901), 147.

${ }^{39}$ R. R. Marett, “Presidential Address: The Transvaluation of Culture,” Folk-Lore 29:1 (1917): 25, 30.

40 Marett, “Transvaluation of Culture,": 29-30.

${ }^{41}$ Marett, "Preface," in Anthropology and the Classics: Six Lectures delivered before the University of Oxford (Oxford: Clarendon Press, 1908), 4.

42 Marett, "Preface," 4; Lang, "Homer and Anthropology," in Marett, ed., Anthropology, 60.

${ }^{43}$ Frederic W. H. Myers, “Greek Oracles,” in Essays: Classical (London: Macmillan, 1908), 5-6. On constructions of colonial subjects as children, see Bill Ashcroft, On Post-Colonial Futures: Transformations in Colonial Writing (London: Continuum, 2009), 36-54. ${ }^{44}$ Lang, "Tylor," 17. 45 Myers, The Human Personality and its Survival of Bodily Death, 2 vol. (London: Longmans Green, 1903), 1: 249. 46 Tylor, Primitive Culture, 17, 156.

47 DeMoor, “Andrew Lang versus W. D. Howells,": 417.

48 Lang, "Protest of a Psycho-Folklorist,": 236-248. In his entry on "Psychical Research,” Lang reveals both the debts he owed to Myers, and points to "inconsistencies" within Myers's posthumously published work (London: Encyclopaedia Brittanica, 1911), 54447.

${ }^{49}$ Lang's disparagers included Sir James George Frazer. See Roger Luckhurst, The Invention of Telepathy (Oxford: OUP, 2002), 160-67, which offers one of the most nuanced analyses of Lang's place within both anthropology and psychic research. 50 Lang, “General Essay,” 23. 
${ }^{51}$ Luckhurst, Invention of Telepathy, 108.

52 Myers, “Modern Poets and the Meaning of Life," Nineteenth Century, 33 (1893):105;

“Multiplex Personality,” Nineteenth Century 20 (1886): 659.

53 Myers, “Greek Oracles,” 18.

${ }^{54}$ See, for example, Fred Kaplan, Dickens and Mesmerism (Princeton: Princeton

University Press, new edn 1995); Stephen Connor, “'All I believed is true': Dickens

under the Influence", 19: Interdisciplinary Studies in the Long Nineteenth Century 10

(2010) https://www.19.bbk.ac.uk.

55 Rosemarie Bodenheimer, Knowing Dickens (New York: Cornell University Press, 2007).

56 Walter Bagehot, “Charles Dickens,” National Review 7 (1858): 458-86; Lang, “Boys,” Cornhill Magazine 47 (1883): 284-91.

${ }^{57}$ See Peter Melville Logan, “G. H. Lewes and Hippolyte Taine on Dickens," Victorian Literature and Culture 46:1 (125-42); G. H. Lewes, "Dickens in Relation to Criticism," Fortnightly Review 11 (1872): 141-54.

58 Lang, “General Essay,” xix.

${ }^{59}$ Lang, “Romance and the Reverse," St James's Gazette 7 Nov 1888: 3-4.

${ }^{60}$ Hubbard in Lang, Selected Writings, 3:130. The view of Lang's Dickens criticism as a rebuttal of the aesthetes was made by G. H. Ford in 1955, and is repeated by Hubbard. See Ford, Dickens and his Readers (New York: Princeton University Press, 1955), 200. ${ }^{61}$ Christine Ferguson, "Reading with the Occultists: Arthur Machen, A. E. Waite, and the Ecstasies of Popular Fiction," Journal of Victorian Culture 21:1 (2016): 40-55. I am also grateful to Alex Murray for sharing his knowledge of Machen. 
${ }^{62}$ Arthur Machen, Ritual and Other Stories (Layburn: Tartarus, 2011). The tale appears to have been written for The Children of the Pool (1936) but was not included in that collection. Machen, The Great Return (London: Faith Press, 1915), 12, 79. 63 Machen, Hieroglyphics (London: Grant Richards 1902), 199. ${ }^{64}$ Machen, Hieroglyphics, 201,12,10, and “Introduction," A Handy Dickens (London: Constable, 1841), xv-xvi. Machen appears to slightly misquote Lang's article "Phiz", reproduced in his Lost Leaders. Ferguson also notes Machen's references to Pickwick as a modern Odyssey; my own reading sees Machen's invocation of Homer as retaining some of his elitism.

65 Machen, $\underline{\text { Hieroglyphics, }} 196$.

${ }^{66}$ Chesterton, Charles Dickens, 83.

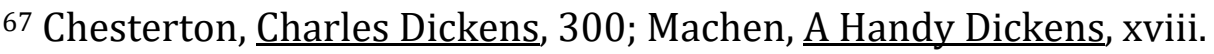

${ }^{68}$ Chesterton, Charles Dickens, 300.

${ }^{69}$ Huysmans, Against Nature, trans. Robert Baldick (London: Penguin, 2003).

${ }^{70}$ On Machen reading Huysmans, see Mark Valentine, Arthur Machen (Glamorgan: Seren, 1995), 18.

${ }^{71}$ Chesterton, Appreciations, 2-3.

72 Machen, "Lost Books," in Bridles and Spurs (Cleveland: Rowfant Club, 1951). Machen also consciously echoes Sylvia Townsend Warner in The Week-End Dickens (London: Maclehose, 1932).

${ }^{73}$ Lang, Letters to Dead Authors, 13-14.

${ }^{74}$ Lang, “Dickens,” Essays in Little, 147.

75 Connolly described Lang and Butcher's translation as “blurred by a Wardour Street Nordic fog": see Enemies of Promise (Chicago: University of Chicago Press, 2008), 216. 
S. H. Butcher and A. Lang, The Odyssey of Homer Done into English Prose (1879). Revised edn (London: Macmillan, 1897), xii.

${ }^{76}$ Marett, “The Psychology of Culture Contact,” Folk-Lore 28:1 (1917): 14.

77 Chesterton, Appreciations, 11-12.

${ }^{78}$ Chesterton, “On Primitive Religion," Illustrated London News 9 May 1925, and “The Death of Mr Andrew Lang," llustrated London News 10 August 1912, in Collected Works of G. K. Chesterton, 37 vol. (San Francisco: Ignatius Press, 1986-2012), 33: 551 and 29: 342; Chesterton, Appreciations, 224. See also “Mr Wardle and Napoleon," Illustrated London News 23 May 1925, in Collected Works 33: 557-61 in which Chesterton references Machen's most recent discussion of Pickwick. ${ }^{79}$ Edward Clodd, "George Meredith: some recollections," Fortnightly Review 86 (1909): $19-31$.

${ }^{80}$ Lang, The Homeric Hymns, 60.

${ }^{81}$ Marett, “Psychology of Culture Contact”:15.

${ }^{82}$ Marett, “Psychology of Culture Contact":23.

${ }^{83}$ Marett, "Psychology of Culture Contact":14; Marett, Psychology and Folk-Lore (London: Methuen, 1920), 75, 127.

${ }^{84}$ Lang, Adventures Among Books, 37.

${ }^{85}$ Sebastian Lecourt, Cultivating Belief: Victorian Anthropology, Liberal Aesthetics and the Secular Imagination (Oxford: OUP, 2018), 189. Reid makes a similar point. ${ }^{86}$ Lang and X, A Working Man, “The Reading Public,” Cornhill Magazine 11 (1901): 94. ${ }^{87}$ Lang, “Examinations in Fiction," Cornhill Magazine 10 (1901): 80-89. 88 Lang, Lost Leaders (London: Kegan, Paul Trench, 1889), 126. 
${ }^{89}$ Lang, "Examinations": 80, 89. Oxford had debated introducing English literature in 1886 and 1887, while some London colleges already had an established syllabus: see Alan Bacon, "English Becomes a University Subject: King's College London as Pioneer," Victorian Studies 29:4 (1986), 591-612. 